\title{
The Foreign Historical Thought and the Historiographical Realities
}

\author{
Emilia Ayubovna Sheudjen
}

Ruslan Aslanovich Tleptsok

Nurbiy Aslanovich Pocheshkhov

Federal State Budget Institution of Higher Professional Education «Adyghe State University» (ASU), 385000

Maikop, street Pervomayskaya, 208, Russian Federation; Email: nisadgu@yandex.ru

\section{Doi:10.5901/mjss.2015.v6n5s1p509}

\begin{abstract}
The article deals with the problems related to the nature and significance of the impact exerted by the foreign historical thought on the historiographical process in Russia. The perception of the ideas that emerged in the Western European historical studies was not a simple matter. The desire and will were not enough. There was a necessity for a more extensive and free system of thinking, the removal of ideological prohibitions and restrictions from the sources, the advanced ability to conduct a scientific dialogue, the emergence of a new "population" of historians capable of thinking in contrast to the established tradition, and the development of an international system of scientific communication (international scientific conferences, system of grants, etc.). Today, when the community of Russian historians reaches a new level of understanding of the basic theoretical and methodological problems, it is especially important for the hard won surveys of the recent decades not to lead to the formation of new labyrinths, and, what even worse, dead ends.
\end{abstract}

Keywords: historical thought, breaking of isolation, research tradition, competing ideas, transformation of ideas, the North Caucasian historiography.

\section{Introduction}

In recent years, the efforts have been made towards ascertaining and analyzing the changes in Russian historical science of the last decades. Among them, we could not but highlight the process of internationalization of historical knowledge, breaking of Russian science's isolation from the world science. For a number of decades, under the influence of external pulses, the historical science has almost changed its skin, but still it is not so easy to understand how the ongoing processes reflect the organic of the historiographical movement, and moreover, what the "price" for the achieved breakthrough is.

During the relatively short time, dozens of fundamental works on social and human sciences written by the Western researchers were translated into the Russian language. The western epistemological paradigms were translated, the interdisciplinary models and methods of learning the past (historical anthropology, historical psychology, history of mentality, gender history, etc.) started to be actively developed. Despite the bewitching charm of the "novelty" ("new new history," "new old history," "modern history," etc.), there was an increasingly strong feeling that the unified river of history split into separate streams that were running away from each other farther and farther, and the "circuitous paths" did not always lead to the desired results.

Casting a critical eye towards the horizons of contemporary historical knowledge, analyzing the "fashionable" research considerations, the endless epistemological surveys of modernism and postmodernism, Ankersmit claims that neither the paths and discourses nor the narratives, categories, and "language games" are able to give a complete understanding of the past. Moreover, he states a shocking remark: the past as such must always "terrify" people, first of all, by the inability to reach the horizon and overcome its illusory proximity (Ankersmit, 2007).

The perception of the ideas emerged in the Western historical science, turned out to be not quite a simple matter. The desire and will were not enough. There was a necessity for a more extensive and free system of thinking, the removal of ideological prohibitions and restrictions from the sources, the advanced ability to conduct a scientific dialogue, and the development of an international system of scientific communication (international scientific conferences, system of grants, etc.). And of course, the time required for the emergence of a new "population" of historians capable of thinking independently, in contrast to the theoretical positions and experience in historical writing of their teachers. 
Russian historians started noticeably experiencing the complex of inferiority, moreover, of professional "deprivation." Several years ago, after reading Toynbee's memories of his Oxford years of studying, of the "set" of requirements that made the concept of "classical" university education, and especially of his grand tour along the modern "Greco-Roman" world that completed his higher education, many people felt regret having realized that even the most capable Russian university graduates did not have those opportunities (Toynbee, 2003).

The borrowing of ideas did not really mean that they would effectively "work" in the Russian conditions characterized by a huge amount of "white spots," ideologically oriented range of problems, the prepared source base, and the lack of knowledge of foreign languages. The overcoming of these circumstances required time and gradualness. Given that Russia continues to divide pronouncedly science on a "center - periphery" basis, a relatively small group of historians assumed the role of "intermediaries" in the translation of the new ideas. As an example, it is enough to turn to the works of Gurevich, and to the established by him almanac "Odyssey," which became the country's first periodical focused on the reception of the foreign methodology of historical science.

\section{Methodology}

The idea of the historical knowledge modernization not supported by the sufficient experience in working within the space of the competing theoretical ideas has led not so much to the development of new theories and research techniques, as to the practice of citing extracts from the works of individual authors, which was already well proven in the historiography of the Soviet period ${ }^{1}$.

Herewith, there was an increasing enhancement of the understanding that innovations led at least to the depreciation of the previous times due to their anachronistic nature, and as maximum-to the denial and equipollent breath thereof. Moreover, the phenomenon of depreciation of the past entails the "growing feeling of alienation," and dulls the sense of duty against the predecessors. In particular, the opportunity to reform the historical science by improving the Marxist methodology of history was missed (Pocheshkhov, 2014).

No attention was paid to the experience of the neo-Marxist and the renovated socio-philosophical and economic concepts aimed at "inclusion" of the Marxism into the realities, into the problematic context and research practice of the past century. Despite criticizing many of the provisions of the "old Marxism," many European thinkers not belonging to the orthodox Marxists started perceiving the significance of its basic methodological positions. For example, famous French intellectuals such as Claude Levi-Strauss, Michel Foucault, and Lucien Goldmann paid tribute to neo-Marxism; while in Russia, the criticism of Marxism was virtually reduced to the complete "refusal" and attempts of "oblivion."

Moreover, the broken out total criticism of Marxism enriched the "battles for history" with the "scorched earth" tactics. Once, the most "enthusiastic" sovietologists could not dare to even dream thereof. However, the problem of the critical perception of the ideas of foreign researchers yet has not lost its relevance today, when the Caucasian subject matter once again has become one of the most important themes in the global policy, though within the framework of a completely different political era, but still with the same, in fact, political actors. It is characteristic that Z. Brzezinski, who presents geopolitics as a game on a "chessboard," indicates the Caucasus as one of the most important areas, the control over which involves many positional advantages. This fact suggests not only the political significance and "inclusion" of the region in the global political scenario, but also the insufficient resolution of the research problems of the Caucasus (Tleptsok, 2014).

Today, when the passions have died down a bit, it becomes possible to try to give an objective assessment of the recent historiographical past, to present a "real" view of the historical science status, its place in the system of ideological confrontation of the opposing social systems, to understand the power of the total fight against the "bourgeois falsifiers of history." It is important to realize that despite the strong methodological orientation inherent in the historical publications of that time, this is a significant part of the historical, more precisely, of the historiographical heritage, a specific scientific phenomenon of the twentieth century.

The historical science in modern Russia is presented as an aggregate of the local groups of researchers that independently select the theoretical approaches and research methodologies. Moreover, they in every way strive to lobby through their contributions proving the undeniable verity of the researches provided, discrediting the efforts of other researchers with an uncompromising attitude of the competitive practices. Usually such communities of scientists emerge around the scientific schools, seminars, and subject-oriented periodicals. All the others act as the "allies" or opponents in the waken war "without rules."

${ }^{1}$ Herewith, the attempts, being almost anecdotal in their naivety, manifested themselves to maintain the prestige of a polyglot: the reference shows the publication in its original language, and in the text, the extracts from the translation are cited. 
At the same time, it is impossible to understand the real outcomes from the transfer of historic ideas without perceiving the way and degree of penetration of the new ideas into the historiographical process at the level of the Russian regions. The North Caucasian historiography could be one of the typical examples in this regard. Originating as the practice of historical writing, it covered a difficult path of development based on the ideas of romanticism, positivism, and Marxism, was affected by the "challenges" of modernism, and, having overcome the "time of doubts," acutely felt the need to establish the new foundations of the historical science (History and Social Sciences [HSS], 2002). The development of the historical thought in the region has reached such a milestone, when the further progress depends on the degree of development of the theoretical and methodological problems, and on the overcoming of the sharp polarization of various conceptual approaches.

Today the definition of "regional history" becomes commonly accepted within the scientific community, since it possesses greater certainty as compared to such concepts as "home science" and "local history," enabling the study of the events of various configurations and scale (Shmidt, 2000). At the same time, we observe an increasing approval of the view that the purpose of cognition and representation of the historical past can be achieved in different scales-local or regional, national, or universal.

However, despite the recognition of the importance of the regional studies, there is a discernible trend of classifying them as "provincial" science in Russian historiography. Apparently, it would be more efficient to transfer the research interest from the enthusiastic study of the "phenomenon of provincialism" to the arbitrariness of the concepts of "province" and "center" in the context of the modern Russian history. The similar differentiation with respect to historiography looks even less sustainable. It is clear that the reference to the history of a particular region leads to a change in the research space, which a priori does not mean the less theoretical and methodological significance of such researches and their "provinciality."

When the historians of the North Caucasus drew their attention to the incorrectness of such assessments, their comments were perceived as an ambitious reflexion. Now, the historians of "center" have also pondered their meaning. Repina wrote, "I still consider it expedient, if possible, to avoid denoting the scientific directions by the words overloaded with connotations, for example, such as the epithet "provincial" (Repina, 2011). Apparently, some historians need a deeper understanding of the current situation in the historical knowledge in order to overcome the complex of "overlord" in the analytical assessment of the status of the North Caucasian historiography. In the scientific world, the ideas are spread along the very complex trajectories: some are underpinned by the intellectual insights on the level of regional history, while others emerge due to the analysis of the processes typical of the broader space of history.

It must be admitted that the interest in the issues of historical and theoretical nature is increasingly becoming a reality of the process of historical knowledge development. The questions of theory and methodology of the North Caucasian history are taking a more prominent place: some special works have appeared, the authors of which strived to generalize the experience of the historical knowledge development within the individual national-administrative entities of the region (Sheudzhen, 1997; Patrakova and Chernous, 2000; Borov, 2005; Kuz'minov, 2006; Karamurzov et al., 2006; Dzidzoev, 2010). The establishment of the historiographical tradition is largely substantiated by the scientific and coordinative activity of the North Caucasian scientific center of higher education, by the journals published therein, and by the revival of the tradition of holding the conferences of Caucasiologists.

Over the last decades, the theoretical issues of the North Caucasian history have been attracting the increasing number of historians, philosophers, and sociologists, while the interest in the problems of the theory and methodology of history has been enhanced. However, it was not managed to establish the rational dialogue relations between them, and to find out the persons involved in the theory of history and practice of historical writing. Despite the fact that hundreds of historical works were created, most of them remain on the narrative level, and extremely rarely "reach" the level of philosophical and theoretical generalization.

Therefore, the following question arises-whether the base of the historiographical sources on the history of the peoples of the North Caucasus capable of becoming a basis for the philosophical generalization is sufficient. A pragmatic meaning was acquired by the assertion of Ankersmit that the philosophy should not claim the advancement of the knowledge base. It is much more useful for the philosophers to focus "on the outcomes of a scientific or historical research" (Ankersmit, 2007). The nature of such relations or the absence thereof becomes significantly apparent at the level of modern historiography, including the North Caucasian one.

With all the nuances, the appeal to the ethnic history of the peoples of the North Caucasus allows collecting the important empirical material, based on which it is possible to set and comprehend the problem of variant development of the peoples within the unified time-space dimension. Herewith, it is important to see the integrity of the processes not only within the territorial boundaries of the region, but also in the possibility of entering into other, broader research spaces (of national history, and due to the presence of diaspora groups, possibly of global history). 
Herewith, based on the concepts of the linearity of progressive development, it is the traditional way of life, in which many researchers still perceive the manifestation of stagnation. Today, the approaches to this problem have started to change fundamentally. In philosophy of history, along with the systemically presented processes that are characteristic of the large-scale complex societies (Shpengler, Sorokin, laspers, Toynbee, et al.), an analysis of the experience in interaction of the peoples with different cultural traditions is also provided. In his brilliant book "Civilization," FernandezArmesto with complete certainty asserts that strictly speaking the "primitive societies" do not exist at all: all of us are the result of the same long evolution" (Fernandez-Armesto, 2009).

In the XX century, a scientific direction emerged, the supporters of which challenged the modernization theory arguing the need to correct the established understanding of the ethno-cultural diversity, the feasibility of cultural traditions, their interaction and collision. With account for these ideas, it is worth to note the statement of a question on the cultural frontier in the context of the historical experience in the cultural interference of the people of the North Caucasus.

It is quite logical that the attention focus shifts to the ethnic communities being traditionally bound by the cultural and historical community. This is the fact that especially annoys some of the historians that insistently associate the development of the modern "national historiography" of the North Caucasus with the establishment of the political mythology. The statement that "in the North Caucasus and other regions, the vulgar pseudo-scientific historiography has become a notable social phenomenon, take roots into the popular mentality, and contributes to the interethnic alienation..." (Bulygina) sounds at least surprising. In connection with such statements, we would like to ask a student's question: are these "deadly sins" of the modern historical knowledge related only to the national, moreover, to the North Caucasian historiography, or do they have wider areas of distribution and genetic bases?

The cultural ideals, moral values, and religious principles played an important role not only in the development of the individual societies, but also in the consolidation of nations. Moreover, the modern world experience does not exclude that the small-numbered peoples, as the participants of the history, are able to establish, learn, and use their own historical experience. At the same time, the study of the intercultural interaction experience can "fit" the themes not only of the regional, but also of the universal history.

The ethnization of the North Caucasian history is quite a natural process for the young historiography. Moreover, such concepts as "native land" and "indigenous people" by no means are the "chimeras" of the regional identity. On the contrary, they are quite characteristic of the human desire to understand "who he is, to and from where he is going." The historians must hardly be concerned with the fact that peoples strive to recover the historical memory (Sep', 2006). The "wars of memory" can be avoided not due to the prohibitions or fear of the increasing nationalism, but due to the overcoming of the mass amnesia. The process of interethnic synthesis that began in remote ages instilled the mosaic North Caucasus with the monolithic status, which does not exclude contradictions. These circumstances should be rigorously considered by addressing the problems of regional history.

As compared to other territories of Russia, the North Caucasus region is a complex configuration of numerous indigenous cultures based on the historically established features of the traditional institutions and the practices of public life. The study of the contact zones with the frontier sociocultural characteristics that were formed based on the cultural, economic, and everyday interactions between various groups of population in the administrative entities of different configurations (district - region - republic, ethnically "twinned" republics), is of particular importance. Of course, the development of such issues will require the combined efforts of sociologists, cultural experts, linguists, and psychologists.

Today, the scientific community is reaching a new level of understanding of the principles and methods of the regional history perception, including the reaction to the publications of foreign authors. It is exemplified by the problem of the North Caucasian Frontier. The origins of this concept root to the Frederick Turner's "Frontier in American History" (1893) that is a cult for the Americans. The main provisions of this theory are as follows: a frontier is a boundary between barbarism and civilization; the territory of dynamics and continuous refreshment of life.

In Russia, in the second half of the XIX century, somewhat earlier than the Turner's theory, the theory of colonization was established, which was most consistently developed by Kliuchevskii. The American history and the Russian history were largely considered as the history of colonization by Turner and Kliuchevskii, respectively. The existence of open spaces, their gradual development, the advancement of the American settlements to the west, and of the Russian settlements to the northeast and southeast were considered as the most important factor of development. Kliuchevskii emphasized, "The history of Russia is the history of a country that is being colonized... Migration and colonization of the country were the main facts of our history, which were closely or remotely related with all the other facts" (Kliuchevskii, 1987). Each theory passed its own way of development. But while the ideas of Turner became the benchmark for the American historiography, and in the following years were actively developed and criticized, moreover, after the World War II came into widespread acceptance in the European historical science, the Kliuchevskii's 
understanding of the process of colonization as "development" of the new spaces was on the contrary completely substituted by the Marxist interpretation of this phenomenon. In recent decades, against the background of the mass interest in the foreign historiography, in the Russian history there have been vigorous attempts to apply the approaches developed by the researchers of the American West to the history of individual regions of Russia (Siberia, the Far East, Bashkortostan, etc.) and even to the history of individual cities. In particular, the materials on the issue of the "Siberian frontier" are literally filling the Internet.

Among the territories of the so-called Russian frontier, the North Caucasus region occupies a special place. Therefore, the article "Lines of Uncertainty: the North Caucasus "Frontier" of Russia" by Thomas M. Barrett published in the first volume of the anthology "American Russian Studies" is of great interest (David-Fox, 2000). The author of this article attempts to apply the approaches developed by the researchers of the American West to the history of the North Caucasus. According to Barrett, this technique will help to overcome the existing in historical science stereotypes in the study of the region's history as the history of conquest, repression, and rebellion of the local population, or as the history of rapprochement and friendship among the peoples. However, the historiographical situation is not so simple. First of all, it is important to note that in recent years the idea of frontier has undergone significant changes, become more concise and diverse. However, the modern researches often continue to interpret it as the boundary between the populated and unpopulated territories, "the meeting place for savagery and civilization" (American and Siberian Frontier [ASF], 1997). With regard to the North Caucasus, at least two important issues were found out: firstly, the meaning of the "uninhabited" lands and, secondly, the way to assess the "involvement" of the peoples of this region into the civilizational processes.

The geographical features of this region, its location on the "abutment" of Europe and Asia from time immemorial have been the cause of the increased attention to the Caucasus demonstrated by the great powers, primarily by Greece, Byzantium, Russia, Turkey, and Iran. The attempts to strengthen their positions in the region were actually made by all the contiguous state formations, the aim of which was to expand the territorial boundaries, and to establish control over the most important economic and trade routes. In the whole field of history, the contiguous territories emerged in this region. They had specific characteristics and different degree of sociability with other nations. However, the region has never been perceived by the surrounding world as the "unpopulated" territory. Moreover, the level of development of the autochthonous peoples contributed to the establishment of the longstanding contacts in various spheres of public life.

With the historical development, the concept of the "contiguous" world has become more complicated. Thus, the widely known facts allow us to suggest that contiguous territory between the peoples of the North Caucasus and Russia existed for many centuries acquiring various configurations from the conventional "contact zone" to the strictly separating military-strategic lines. In this sense, we can agree that the peoples of the North Caucasus for centuries existed in the southern zone of the Russian (European) frontier. However, the territory on the other side of the conditional border had never been perceived as unpopulated free space.

No less important is the consideration of the issue of the North Caucasian frontier as the border between the "civilization" and the "barbarism." Michael Khodarkovskii, an American professor of the Russian history, proposes to consider the North Caucasian region as a place where "the meeting of the two different worlds took place: the mosaic world of the pagan and Muslim societies, existed in the Caucasus, with the primitive political organization and economy, based on the low developed herding and subsistence farming, and the world of people who came here from Russia with its system of bureaucracy and war machine, geopolitical interests and missionary ambition of the age of Enlightenment" (Khodarkovskii).

In recent years, the concept of the highland civilization is vigorously introduced into the scientific use. The civilizational approach could appear to be very promising for the understanding of specifics of the social system of the peoples of the North Caucasus, the level of their cultural, political, and economic development. Of course, the application of such an approach requires the understanding of many theoretical ideas, in particular, clarification of the scope of the concept "civilization." Regarding the peoples of the North Caucasus, apparently, it is possible to use the variant of historical interpretation, which is based on the idea of local civilizations as a complex symbiosis of indigenous communities with the unique features of the socioeconomic and political organization, which are developing within the special geographical and climatic conditions and differing by a high level of the cultural and spiritual interethnic integration.

\section{Summary}

Today, it is important for the theoretical and methodological surveys not to lead to the formation of new labyrinths, and, what even worse, of dead ends. Given the acuteness and largely the controversial nature of the problems concerning the North Caucasian history, there is a need to understand how it fits into the process of development of the historical 
science, how the basic concepts "work" at the regional level, and what is the degree of the specificity expression of such studies. The development of regional historiography is not just simply working in favor of the Russian history, but also contributes to its enrichment with the ideas of the historical process variability. Moreover, this is not about the prevailing process of the historical knowledge, but about the possibility and importance of the regional studies.

The international conferences, forums, and round tables that have taken place in recent years in the North Caucasus are of particular importance for the understanding of the current situation. Thanks thereto, it became possible to perform a direct exchange with the obtained results of the researches conducted, to become aware of their relevance and prospects. However, the arrangement of these meetings reflected the low level of interest in the most important theoretical and methodological problems, and often the reluctance, and perhaps, the inability to conduct a dialogue.

The development of the Internet does not eliminate the problem of the mobile awareness of the community of historians on the nature and orientation of the ongoing researches. A small run of the published works, the high cost of subscriptions to the specialized periodicals, the payment for the right to publish one's works, a fare from rational system of compilation of the Internet resources do not allow to establish the "working" communications between the individual researchers, local groups, and the communities of scientists. It becomes increasingly difficult to understand the logic of the editorial boards working with the periodicals, the structure of the printing area organization, and the nature of the materials selection. Moreover, the clearly apparent ideology of "denying" the importance of the predecessors' works, and the inability to hear the opponents and to respect the followers do not support the authority of history and of the professional community.

The stylistics, or, to be more precise, the language of the contemporary debates on the Internet, which increasingly resembles a "fight without rules," is even more puzzling It has become normal, to use marginalized vulgar jargon instead of arguments when proving defending one's own viewpoint. As a result, the awareness of the intellectual importance of the researches conducted in human sciences is lost.

However, despite the difficult situation, for the "national" historians of the North Caucasus, the pursuance of an objective representation of the past has become not only a professional, but also a moral duty. In the conditions of the revolutionary "withdrawal," the ethnic communities have become aware of the meaning and significance of their own historical experience, and the threat of the thoughtless breakage of the "link of times." This is something that we often forget about, when adopting a role of the peremptory judges regarding the works written by the authors gone to a better world and thus unable to defend their views and beliefs, and moreover, to resist the "raider seizures" of their heritage.

It is important to overcome the "one-dimensional apologetics," which is based only on the positive assessments of everything that once happened in the country and in the region in the field of historical knowledge. It is clear that with this approach, such tragic phenomena as subjectivism, professional ignorance, and disregard of the devastating events that affected the historical knowledge development, and moreover the mentality of the scientific community, will inevitably "drop off" the field of our vision.

And one more thing. In his note "On Ancient and Modern Russia" (1811), Karamzin distinguished the importance for Russia of borrowings from the European culture that became common already in the pre-Petrine times, but at the same time the author emphasized that the changes were always a mere application "to ours and a combination of the new and the old." As a result, he concludes that "we have become the citizens of the world, but in some cases, are no longer the citizens of Russia" (Karamzin, 1991).

In general, there are numerous problems in this issue. Over the past century, the historical science has experienced a deep inner transformation: the generations of historians were altered, the object and methods of historical cognition were modified, the attitude to the documentary evidences was determined. At the same time, we cannot ignore the fact that history was and largely remains a "foreign country," where the researcher's position mainly resembles his stay in a foreign country (Lowenthal, 2004). The main thing for historians is not to be lost in the illimitable spaces of the unknown, and on the contrary to continue insistently their way to the attainment of truth by encouraging each other with word and deed.

\section{References}

Amerikanskii i Sibirskii Frontir [The American and Siberian Frontier] (1997). Amerikanskie Issledovaniia v Sibiri - The American Studies in Siberia, 2. Tomsk [in Russian].

Ankersmit, F. (2007). Vozvyshennyi Istoricheskii Opyt [The Sublime Historical Experience] (pp. 5). Moscow [in Russian].

Ankersmit, F. (2007). Vozvyshennyi Istoricheskii Opyt [The Sublime Historical Experience] (pp. 204, Oleinikova, A.A., Trans.). Moscow: Evropa [in Russian].

Borov, A.Kh. (2005). K obnovlennoi kontseptsii natsional'noi istorii: istoriograficheskie itogi i perspektivy [To the updated concept of the 
national history: the historiographical results and prospects]. Istoricheskii Vestnik KBIGI - The KBIGI Historical Bulletin, 1, 3-29. Nalchik: El'-Fa [in Russian].

Bulygina, T.A. Regional'naia Istoriia: Poiski Novykh Issledovatel'skikh Podkhodov [The Regional History: a Search for the New Research Approaches]. Retrieved from: http://history.vuzlib.org`book_0064_page_75.html [in Russian].

David-Fox, M. (2000). Amerikanskaia rusistika. Vekhi istoriografii poslednikh let. imperatorskii period: Antologiia. [The American Russian studies. The milestones in the historiography of recent years. The Imperial period: Anthology] (pp. 163-195). Samara: Samarskii Universitet [in Russian].Toynbee, A.J. (2003). Perezhitoe. Moi Vstrechi [The Experienced. My Encounters] (pp. 23-25). Moscow [in Russian].

Dzidzoev, V.D. Ob"ektivnost' i sub"ektivnost' v sovremennoi istoriografii kavkaza (postanovka voprosa) [The Objectivity and subjectivity in the contemporary historiography of the Caucasus (raising the question)]. Retrieved from: http://kvkz.ru/.../2469-obektivnost-isubektivnost-v-sovremennoj-istoriografii-kavkaza-postanovka-voprosa.html [in Russian].

Fernandez-Armesto, F. (2009). Tsivilizatsii [Civilizations] (pp. 33, Trans.). Moscow: AST Moskva [in Russian].

Istoriia i Sotsial'nye Nauki: Povorotnyi Moment? [History and Social Sciences: a Turning Point?]. (2002). Annaly na Rubezhe Vekov. Antologiia - The Annals at the Turn of the Centuries. Anthology (pp. 11-12). Moscow: XXI Vek. Soglasie [in Russian].

Karamurzov, B.S., Borov, A.Kh., Dzamikhov, K.F., \& Muratova, E.G. (2006). Sotsiokul'turnye Mekhanizmy Severokavkazskogo Istoricheskogo Protsessa: Drevnost' - Novoe Vremia [The Sociocultural Mechanisms of the North Caucasian Historical Process: the Antiquity - the New Time]. Nauchnaia Mysl' Kavkaza - The Scientific Thought of the Caucasus, 3, 68-76 [in Russian].

Karamzin, N.M. (1991). Zapiska o drevnei i novoi Rossii [A note on the Ancient and Modern Russia] (pp. 31, 33). Moscow [in Russian].

Kliuchevskii V.O. (1987). Kurs russkoi istorii. Lektsiia 2 [The Course of the Russian history. Lecture 2] (pp. 49-51). Works in 9 Volumes, Vol. 1. Moscow [in Russian].

Khodarkovskii, M. V korolevstve krivykh zerkal (Osnovy rossiiskoi politiki na Severnom Kavkaze do zavoevatel'nykh voin XIX v.) [In the Kingdom of Crooked Mirrors (The Fundamentals of the Russian Policy in the North Caucasus before the Wars of Conquest of the XIX Century)]. Retrieved from: http://www.sakharov-center.ru/chs/chrus02_3.htm [in Russian].

Kuz'minov, P.A. (2006). Kavkazovedenie na Grani Vekov [The Caucasus Studies at the Turn of the Centuries]. Kavkazovedenie: Opyt Issledovanii: Materialy Mezhdunarodnoi Nauchnoi Konferentsii - The Caucasus Studies: the Experience of Researches: Proceedings of the International Scientific Conference of October 13-14, 2005 (pp. 5-31). Vladikavkaz [in Russian].

Lowenthal, D. (2004). Proshloe - chuzhaia strana [The Past Is a foreign country]. Saint Petersburg [in Russian].

Patrakova, V.F., \& Chernous, V.V. (2000). Istoriografiia Kavkazskoi Voiny: v Poiske Novoi Paradigmy [The Historiography of the Caucasian War: in Search of a New Paradigm]. Nauka o Kavkaze: Problemy i Perspektivy: Materialy I S"ezda UchenykhKavkazovedov - The Science on the Caucasus: Problems and Prospects: Proceedings of the I Conference of the Scientists Caucasiologists of August 27-28, 1999 (pp. 109-113). Rostov-on-Don [in Russian].

Pocheshkhov, N.A. (2014). Istoriia Narodov Severnogo Kavkaza v Sovetskoi Istoriografii: Pozitivnyi ili Negativnyi Opyt? [The History of the Peoples of the North Caucasus in the Soviet Historiography: a Positive or Negative Experience?]. Materialy II Mezhdunarodnogo foruma istorikov - kavkazovedov - Proceedings of the II International Forum of Historians - Caucasiologists of October 15-16, 2014 (pp. 149-153). Rostov-on-Don: Fond Nauki i Obrazovaniia [in Russian].

Repina, L.P. (2011). Istoricheskaia Nauka na Rubezhe XX-XXI vV.: Sotsial'nye Teorii i Istoriograficheskaia Praktika [The Historical Science at the Turn of the XX-XXI centuries: The Social Theories and Historiographical Practice] (pp. 182). Moscow: Krug" [in Russian].

Sen', D.V. (2006). "Chernomoriia" versus "Kuban"': Nekotorye aspekty diskursa imperii i teoreticheskie problemy izucheniia istorii Severo-Zapadnogo Kavkaza kontsa XVIII - nachala XIX v. [The "Black Sea" region versus the "Kuban" region: Some aspects of discourse of the empires and theoretical problems of studying the history of the North-West Caucasus in the late XVIII - early XIX century]. Itogi Fol'klorno- Etnograficheskikh Issledovanii Etnicheskikh Kul'tur Severnogo Kavkaza za 2005 God - The Results of the Folk-Ethnographic Researches of the Ethnic Cultures of the North Caucasus for the Year 2005 (pp. 380-381). Krasnodar [in Russian].

Sheudzhen, E.A. (1997). Problemy Mestnoi Istorii v Novoi Istoriograficheskoi Perspektive [The Problems of Local History in the New Historiographical Perspective]. Izvestiia Vysshikh Uchebnykh Zavedenii. Severo-Kavkazskii Region. Obshchestvennye Nauki The News of the Higher Education Institutions. The North Caucasus Region. Social Sciences, 4, 57-60 [in Russian].

Shmidt, S.O. (2000). Kraevedenie i Regional'naia Istoriia v Sovremennoi Rossii [The Local Studies and Regional History in Modern Russia]. Metodologiia Regional'nykh Istoricheskikh Issledovanii. Rossiiskii i Zarubezhnyi Opyt. Materialy Mezhdunarodnogo Seminara - The Methodology of the Regional Historical Researches. The Russian and Foreign Experience. Proceedings of the International Workshop of June 19-20, 2000 (pp. 11-15). Saint Petersburg [in Russian].

Tleptsok, R.A. (2014). The Caucasus in the Geopolitical Coordinate System. Empires and Nations from the 18th to the 20th Century, Vol. 1, 337. Cambridge. 